\title{
MINERALS AND PHYTOCHEMICAL ANALYSIS OF BITTER MELON FRUITS AND ITS COMPONENTS IN SOME INDIGENOUS AND EXOTIC CULTIVARS
}

\author{
ANÁLISE FITOQUÍMICA E DE MINERAIS DE FRUTOS DE MELÃO AMARGO E \\ SEUS COMPONENTES EM ALGUNS CULTIVARES INDÍGENAS E EXÓTICOS
}

\author{
MAHWISH $^{1}$; Farhan SAEED ${ }^{1}$; Mahr un NISA ${ }^{1}$; Muhammad Tahir NADEEM ${ }^{1}$
}

1. Institute of Home and Food Sciences, GC University, Faisalabad, Pakistan.

\begin{abstract}
The present study was designed to compare the mineral contents and phytochemicals in fruits of some indigenous and exotic bitter melon cultivars. Skin, flesh, seeds and whole fruit of each cultivar were dried at room temperature and ground to fine powder which was packed separately in air-tight plastic jars for analysis. The data revealed that all the cultivars possessed appreciable amount of minerals. Indigenous cultivars possessed higher mineral contents than the exotic cultivars. Black King was found to be desirable cultivar with high amount of potassium, phosphorous, magnesium, calcium, iron and zinc with values of 258.83, 92.92, 46.74, 48.42, 3.90 and $1.78 \mathrm{mg} / 100 \mathrm{~g}$, respectively. Among fruit parts, flesh portion was rich in potassium, phosphorous, magnesium, sodium and calcium followed by skin and seed. The seeds possessed relatively high amount of iron $(4.44 \mathrm{mg} / 100 \mathrm{~g})$ and zinc $(2.80 \mathrm{mg} / 100 \mathrm{~g})$. On the whole, flesh part of Black King is predominated in mineral profile while least quantity was observed in the seeds of Noor. All the cultivars possessed same types of phytochemicals although may vary in their abundance. Phenols, flavanoids, saponins and ascorbic acid were present in abundance in skin and flesh while seeds were found rich in alkaloids and glycoalkaloid. The variations in the chemical composition in fruit and components due to changes in agro-climatic conditions suggest that there is scope for developing cultivars to be grown in wide range of agronomic, climatic and geographic conditions with no effect on its nutrient and phytochemical profile.
\end{abstract}

KEYWORDS: Bitter melon. Momordica charantia. Minerals. Phytochemicals.

\section{INTRODUCTION}

Bitter melon (Momordica charantia L.) is a climbing perennial, tendril-bearing vine belongs to family Cucurbitaceae. Bitter melon is also known as Karella, bitter gourd, balsam-pear, bitter squash or wild cucumber (KRAWINKEL; KEDING, 2006) and is characterized by elongated, warty fruit-like gourds or cumbers which are extensively consumed as vegetable (ASSUBAIE; EL-GARAWANY, 2004). In ancient times, bitter melon was used as a folk medicine to cure variety of ailments. This versatile plant is considered to be commendable of treating almost any disease inflicted on mankind. This may be due to the fact that the plant possesses hundreds of different phytochemical constituents having medicinal values (TAYLOR, 2002). In addition to cure diseases, it is rich in minerals that are required for proper functioning of body.

Calcium, sodium, potassium, magnesium, manganese, iron, and zinc are found in reasonable amount in bitter melon (BAKARE et al., 2010). These minerals are vital in proper functioning of body as calcium has a pivotal role in muscle contraction, in the formation of bone and teeth and in clotting of blood in trauma (PETERS; MARTINI, 2010). Zinc and magnesium are helpful as cofactor in many enzymetic controlled catalytic reactions within the body (AHMED; CHAUDHARY, 2009). Potassium, calcium and zinc play important roles in stimulation of beta cells of islets of Langerhans to release insulin (KAR et al., 1999). Intracellular and extracellular fluid has sodium and potassium which has a role in maintaining electrolytic balance and fluidity across membranes (AHMED; CHAUDHARY, 2009).

Iron is a fundamental component of hemoglobin, myoglobin and metalloenzymes (AHMED; CHAUDHARY, 2009), which is required for oxygen and $\mathrm{CO}_{2}$ transport during respiratory activity and cellular metabolism. To regulate changes in blood $\mathrm{pH}$, this iron containing hemoglobin also serves as buffer (NAIK, 2016). Potassium is also valuable for cardiovascular health and regulation of water within the body. Zinc in bitter melon regulates normal functioning of immune system. Manganese which is essential mineral also found in bitter melon is an important element for a number of enzymes that are involved in production of energy and antioxidant defenses. Mitochondria require manganese for many enzymes to work against free radicals activities.

Bitter melon is thought to beneficial for health and prevent from many diseases due to 
presence of phytochemicals including flavonoids, phenols, terpenes, alkaloids, glucosinolates and isoflavones having antioxidant potential (DREWNOWSKI; GOMEZ-CARNEROS, 2000). It is also a huge reservoir of vitamin A, B-Complex, $\mathrm{C}$, niacin and folate essential for many metabolic pathways.

The assessment of mineral contents and phytochemicals is often become essential in many diet plan strategies. Due to globalization, cultivation of improved varieties ingress from other countries is a common practice. The main focus in cultivation of such cultivars is merely high yield without giving any attention to their nutrient quantity and phytochemistry. No previous information is available regarding introduction of cultivars in a new habitat and subsequent impact on its mineral contents and phytochemicals. Hence, the present study aimed to assess the minerals and phytochemicals in fruits of different indigenous and exotic cultivars of bitter melon. Moreover, skin, flesh and seeds of the fruits were also evaluated to compare the relative abundance of these minerals and phytochemicals in these parts.

\section{MATERIAL AND METHODS}

The present study was carried out in the Institute of Home and Food Sciences at Government College University, Faisalabad. In this study, mineral and phytochemical analysis of whole fruit of different cultivars of bitter melon (Momordica charantia L.) as well as its parts i.e., skin, flesh and seeds was determined.

\section{Procurement of raw material}

Bitter melon cultivars viz., Noor and BG 20 from India; Black King and FSD Long from Pakistan; KHBG-1 and GHBG-1 from China were grown in Vegetable Research Section, Ayub Agriculture Research Institute, Faisalabad. Selection of these cultivars was conceded on the basis of high yield, quality and freshness. Young fruits were collected for minerals and phytochemical analysis.

\section{Sample preparation}

The bitter melon fruits were washed thoroughly under running tap water to remove adhered dirt, dust and other foreign debris. After washing, some fruits of each cultivar were cut to small pieces as a whole. While some of the fruits of each cultivar were peeled separately and seeds were isolated and pulp was cut into small pieces. In this way, skin, flesh and seeds of each cultivar were obtained. These were dried at room temperature for few days. The dried materials were ground further to fine powder by using a small laboratory grinder (Panasonic, Japan, Model MJ-W176P) and passed through a sieve for further refining. After preparation of powder for each category, it was packed separately in air-tight plastic jars for further analysis.

\section{Mineral analysis}

The skin, flesh, seeds and whole fruit of all the cultivars were subjected to mineral analysis following the guidelines of AOAC (2006). The sodium $(\mathrm{Na})$ and potassium $(\mathrm{K})$ were assessed by Flame Photometer-410 (Sherwood Scientific Ltd., Cambridge) whilst, phosphorous (P), magnesium $(\mathrm{Mg})$, calcium $(\mathrm{Ca})$, iron $(\mathrm{Fe})$ and zinc $(\mathrm{Zn})$ were determined through Atomic Absorption Spectrophotometer (Varian AA240, Australia).

\section{Phytochemical screening}

Occurrence of phytochemicals in different samples was noted by following procedures.

Phenols: Presence of phenols was assessed by using Folin-Ciocalteu method following the protocol of Singleton et al. (1999).

Flavonoids: The flavonoid in bitter melon was recorded according to colorimetric method as described by Zou et al. (2004).

Saponins: Preliminary evidence of Saponins was observed by noting froth production in solution as mentioned by Obadoni and Ochuko (2001).

Alkaloids: To determine alkaloids in bitter melon samples, the method of Harborne (2005) was used.

Ascorbic acid: Presence of Ascorbic acid (Vitamin C) was noted by titrating against phenol indo-2,6dichlorophenol, DPIP (Papuc et al., 2001).

Glycoalkaloid: Glycoalkaloid was determined by the method of White (1987).

\section{Statistical analysis}

The results obtained were subjected to statistical analysis using Microsoft Excel 2010 and Statistix 8.1. Level of significance was determined by applying ANOVA and LSD for comparison.

\section{RESULTS AND DISCUSSION}

\section{Estimation of mineral contents}

The mean values regarding mineral contents in bitter melon cultivars (Table 1) depicted that the highest potassium, phosphorous, magnesium, calcium, iron and zinc were found in Black King. The FSD Long was found to be second best cultivar owing to rich mineral composition followed by $\mathrm{BG}$ 20, KHBG-1, GHBG-1 and Noor. 
Table 1. Comparative analysis of mineral contents in fruits of different bitter melon cultivars.

\begin{tabular}{|c|c|c|c|c|c|c|c|}
\hline & $\mathbf{K}$ & $\mathbf{P}$ & Mg & $\mathbf{N a}$ & $\mathbf{C a}$ & $\mathbf{F e}$ & $\mathbf{Z n}$ \\
\hline Noor & $162.17^{\mathrm{e}}$ & $59.58^{\mathrm{e}}$ & $37.22^{c}$ & $51.05^{\mathrm{d}}$ & $25.82^{d}$ & $3.38^{\mathrm{bc}}$ & $1.35^{\mathrm{d}}$ \\
\hline BG 20 & $217.50^{c}$ & $74.74^{\mathrm{c}}$ & $40.02^{\mathrm{b}}$ & $57.61^{\mathrm{b}}$ & $30.42^{c}$ & $3.34^{\mathrm{c}}$ & $1.47^{\mathrm{bc}}$ \\
\hline Black King & $258.83^{\mathrm{a}}$ & $92.92^{\mathrm{a}}$ & $46.74^{\mathrm{a}}$ & $58.24^{\mathrm{b}}$ & $48.42^{\mathrm{a}}$ & $3.90^{\mathrm{a}}$ & $1.78^{\mathrm{a}}$ \\
\hline FSD Long & $235.42^{\mathrm{b}}$ & $84.50^{\mathrm{b}}$ & $40.53^{\mathrm{b}}$ & $54.22^{\mathrm{c}}$ & $41.44^{\mathrm{b}}$ & $3.28^{c}$ & $1.50^{\mathrm{b}}$ \\
\hline KHBG-1 & $176.83^{\mathrm{d}}$ & $68.50^{\mathrm{d}}$ & $33.61^{\mathrm{d}}$ & $61.81^{\mathrm{a}}$ & $32.08^{c}$ & $3.50^{\mathrm{b}}$ & $1.41^{\mathrm{cd}}$ \\
\hline GHBG-1 & $158.83^{\mathrm{f}}$ & $52.08^{\mathrm{f}}$ & $35.23^{\mathrm{cd}}$ & $58.97^{\mathrm{b}}$ & $39.69^{b}$ & $4.00^{\mathrm{a}}$ & $1.35^{\mathrm{d}}$ \\
\hline
\end{tabular}

Superscript letters within the same column indicate significant differences $(\mathrm{P}<0.05)$.

Mineral contents in different parts (Table 2) revealed that the highest $\mathrm{K}, \mathrm{P}, \mathrm{Mg}, \mathrm{Na}$ and $\mathrm{Ca}$ contents were observed in flesh followed by skin while seed contained the least amount of these minerals. On the other hand, seeds are rich source of $\mathrm{Fe}$ and $\mathrm{Zn}$.

Table 2. Comparative analysis of mineral contents in different parts of bitter melon fruit.

\begin{tabular}{lccc}
\hline & Skin & Flesh & Seeds \\
\hline $\mathbf{K}$ & $261.78^{\mathrm{b}}$ & $291.89^{\mathrm{a}}$ & $25.61^{\mathrm{c}}$ \\
$\mathbf{P}$ & $88.78^{\mathrm{b}}$ & $98.22^{\mathrm{a}}$ & $20.49^{\mathrm{c}}$ \\
$\mathbf{M g}$ & $45.89^{\mathrm{b}}$ & $56.11^{\mathrm{a}}$ & $3.23^{\mathrm{c}}$ \\
$\mathbf{N a}$ & $73.28^{\mathrm{b}}$ & $84.11^{\mathrm{a}}$ & $2.27^{\mathrm{c}}$ \\
$\mathbf{C a}$ & $45.56^{\mathrm{b}}$ & $53.42^{\mathrm{a}}$ & $2.21^{\mathrm{c}}$ \\
$\mathbf{F e}$ & $2.94^{\mathrm{c}}$ & $3.29^{\mathrm{b}}$ & $4.44^{\mathrm{a}}$ \\
$\mathbf{Z n}$ & $0.68^{\mathrm{c}}$ & $0.84^{\mathrm{b}}$ & $2.80^{\mathrm{a}}$ \\
\hline
\end{tabular}

Superscript letters within the same row indicate significant differences $(\mathrm{P}<0.05)$.

The minerals in the skin of different cultivars (Figure 1) indicated that skin of Black
King is rich in $\mathrm{K}, \mathrm{P}, \mathrm{Mg}, \mathrm{Ca}, \mathrm{Fe}$ and $\mathrm{Zn}$ with values of $326.33,125.00,56.33,62.33,3.27$ and 0.94 


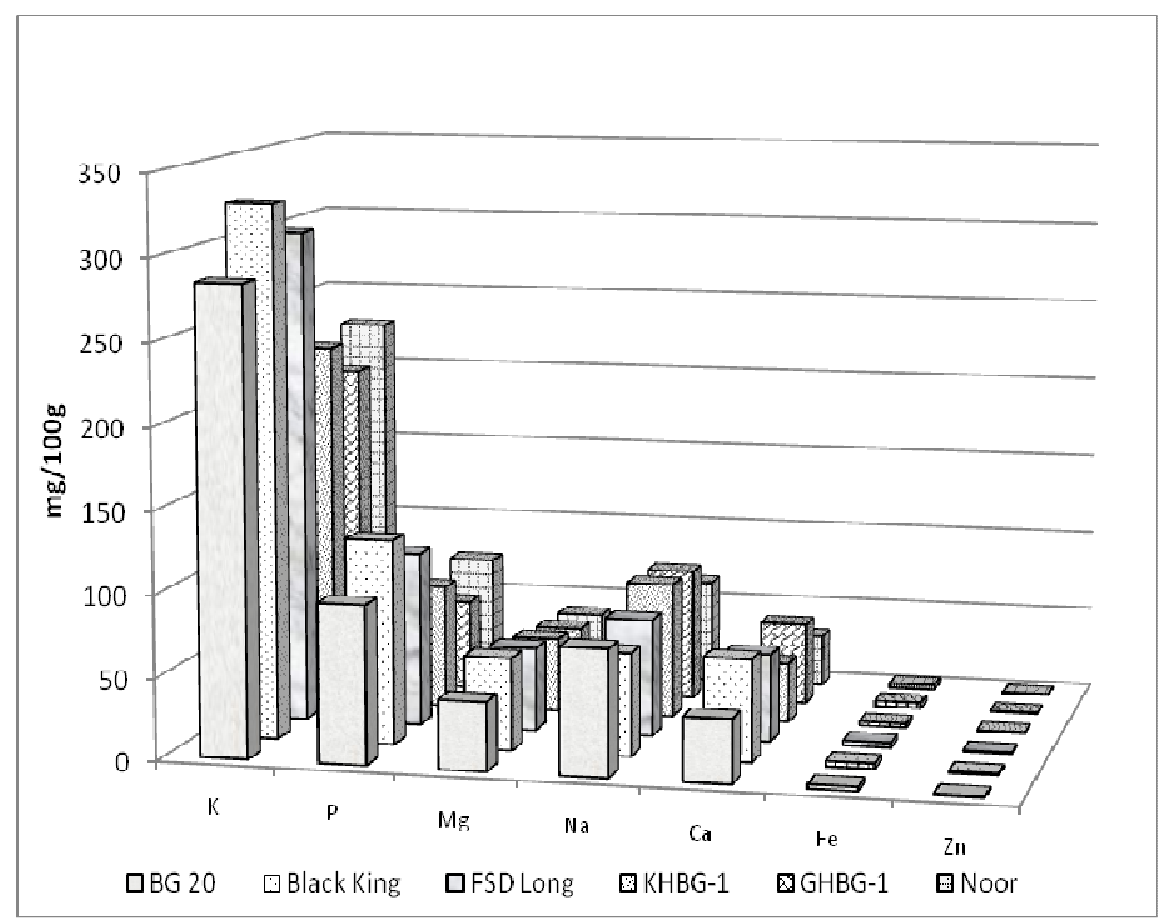

Figure 1. Comparative mineral contents in the skin of different bitter melon cultivars.

The mineral profile in the flesh part of different cultivars (Figure 2) highlighted that K, P, $\mathrm{Mg}, \mathrm{Ca}$ and $\mathrm{Zn}$ were in abundance in Black King with values of $397.00,128.67,64.66,70.33$ and 0.97 $\mathrm{mg} / 100 \mathrm{~g}$ while Na contents are high in FSD Long $(91.00 \mathrm{mg} / 100 \mathrm{~g})$ and Fe contents in GHBG-1 (4.03 $\mathrm{mg} / 100 \mathrm{~g})$.
The minerals in seed portion (Figure 3) showed that $\mathrm{K}, \mathrm{Mg}$ and $\mathrm{Zn}$ were highest in Black King (37.33, 4.63 and $3.52 \mathrm{mg} / 100 \mathrm{~g}$, respectively). $\mathrm{P}$ and $\mathrm{Fe}$ found to be highest (28.67 and 4.91 $\mathrm{mg} / 100 \mathrm{~g}$, respectively) in KHBG-1 while BG 20 possessed comparatively high values of $\mathrm{Na}$ (3.1 $\mathrm{mg} / 100 \mathrm{~g})$ and $\mathrm{Ca}(2.66 \mathrm{mg} / 100 \mathrm{~g})$.

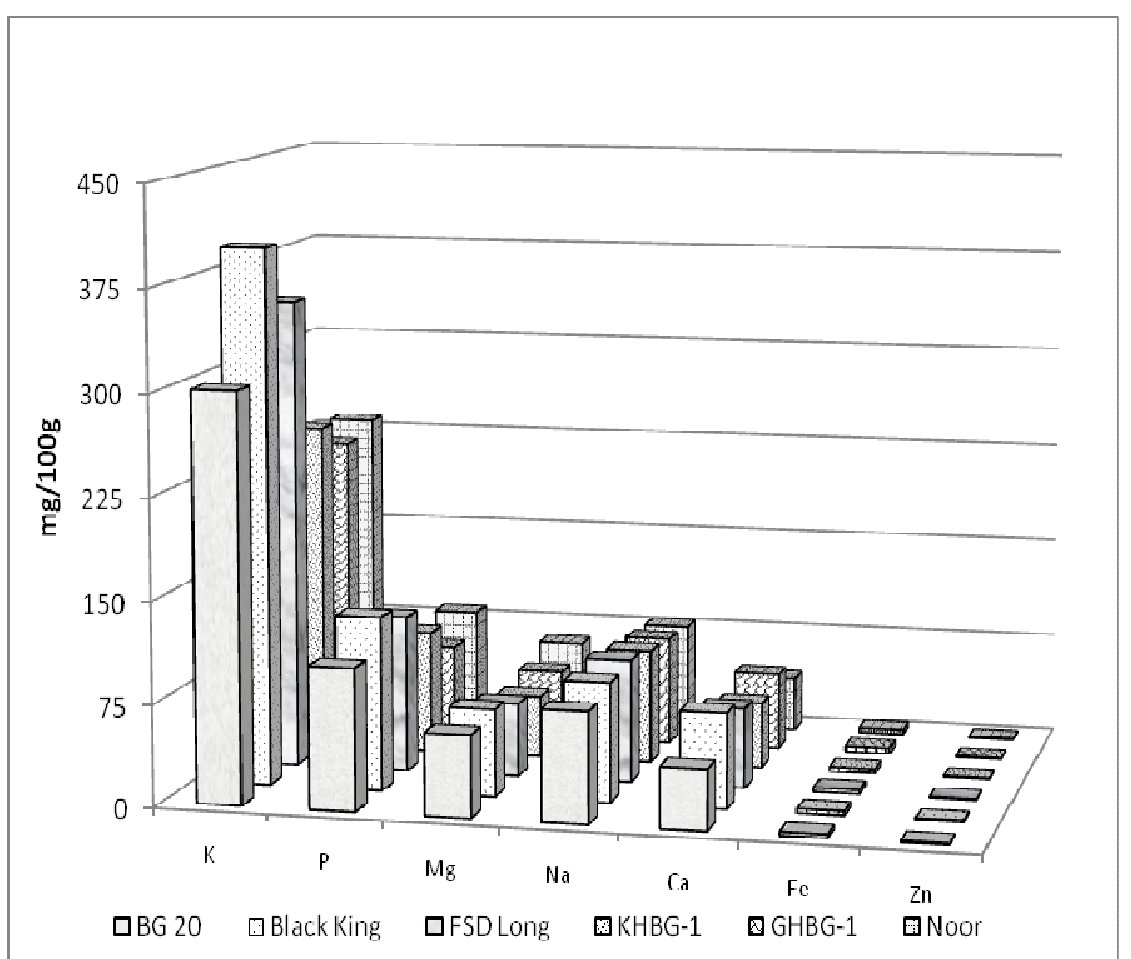

Figure. 2. Comparative mineral contents in the flesh of different bitter melon cultivars. 


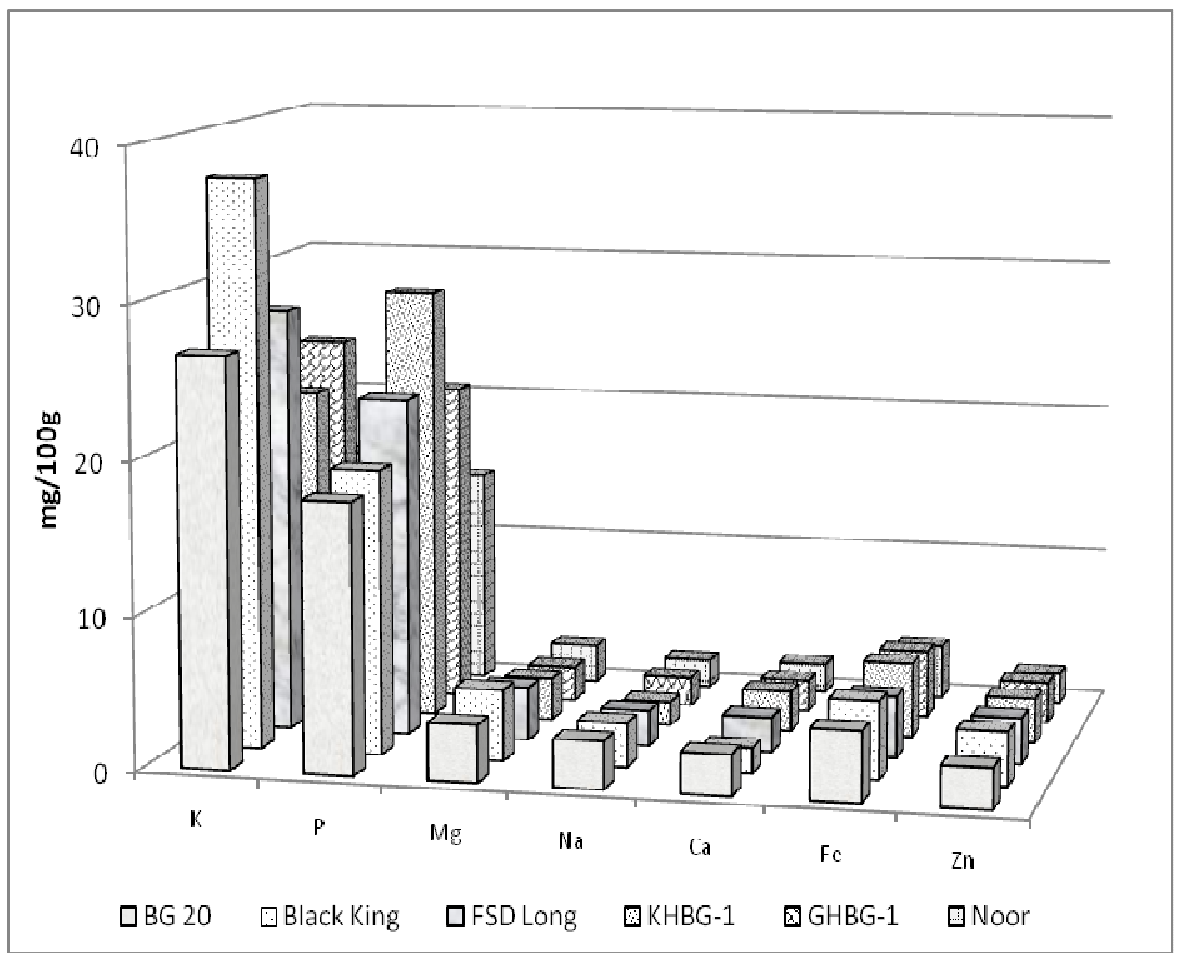

Figure 3. Comparative mineral contents in the seeds of different bitter melon cultivars.

Bitter melon was found to be valuable source of macro and micro minerals. The results regarding potassium contents in fruits of some cultivars were in close conformity with the previous findings of Bangash et al. (2011), Islam et al. (2011) and Aslam et al. (2013) in which they reported higher amount of potassium. In another study, Horax et al. (2010) reported comparable results that potassium contents were much higher in pericarp than the seeds. However, recent investigation by Mathew et al. (2014) reported very low amount of potassium $(3.17 \mathrm{mg} / 100 \mathrm{~g})$ in the seeds of bitter melon than the present results.

The results regarding phosphorous contents are slightly different from the values given by Mathew et al. (2014) reported lower value of phosphorous $(11.09 \pm 0.30 \mathrm{mg} / 100 \mathrm{~g})$ in the seeds of bitter melon than the current findings. This might be due to varietal differences as Ali et al. (2008) also showed differences regarding phosphorous contents in the seeds of three bitter melon cultivars. Similar findings were also reported by Anjum et al. (2013) by comparing seeds of two cultivars and found variations regarding phosphorus contents with values of $135.92 \pm 3.86 \mu \mathrm{g} / \mathrm{g}$ and $146.19 \pm 3.04$ $\mu \mathrm{g} / \mathrm{g}$, respectively.

The present results about presence of magnesium in bitter melon fruits are in harmony with the findings of Bangash et al. (2011) showing $31.00 \pm 0.10 \mathrm{mg} / 100 \mathrm{~g}$ magnesium in this vegetable.
The results are further strengthened by the work of Mathew et al. (2014) portraying lesser amount of magnesium $(3.50 \mathrm{mg} / 100 \mathrm{~g})$ in the seeds of this bitterly taste fruit. In another report, Islam et al. (2011) described the lower magnesium concentration $(16 \mathrm{mg} / 100 \mathrm{~g})$ in bitter melon. Previous findings by Ullah et al. (2011) on fruits of four cultivars of bitter melon showed considerably lower magnesium contents with values in the range of $0.99-1.10 \mathrm{mg} \%$.

Bitter melon is suitable in diet plan strategies as it contained low amount of sodium. Mathew et al. (2014), and Bangash et al. (2011) also reported low amount of sodium in the seeds and edible fruit portion of bitter melon $(2.10 \pm 0.00$ and $31 \pm 0.03 \mathrm{mg} / 100 \mathrm{~g}$ ). According to Horax et al. (2010), seed part contained lower amount of sodium than the flesh part. Aslam et al. (2013) found lesser amount of sodium in bitter melon with value of 7.4 ppm. Hussain et al. (2009) also depicted lesser amount of sodium $45.47 \mathrm{ppm}$ in fruit part of this plant.

Calcium played important role in bone formation and movement of muscles. The results of present mineral analysis regarding calcium $(45 \pm 0.12 \mathrm{mg} / 100 \mathrm{~g})$ are in agreement with the findings of Bangash et al. (2011). On the other hand, higher amount of calcium $(137.69 \mathrm{mg} / 100 \mathrm{~g})$ was assessed by Soomro and Ansari (2005) in whole fruit of bitter melon. Ullah et al. (2011) quantified 
calcium in different cultivars and found wide variations regarding calcium contents. They reported calcium contents in the range of $0.54 \pm 0.30$ $7.00 \pm 0.25 \mathrm{mg} \%$ in these cultivars. Mathew et al. (2014) found out that calcium in the seeds of bitter melon were $3.69 \pm 0.00 \mathrm{mg} / 100 \mathrm{~g}$ which is in close conformity of the present results. Gayathri (2014) and Aslam et al. (2013) reported lesser amount of calcium in bitter melon. Anjum et al. (2013) studied seeds of two bitter melon cultivars and reported relatively large quantities of calcium (425.08 and $399.81 \mu \mathrm{g} / \mathrm{g}$ ) than other minerals. Earlier, Ali et al. (2008) reported calcium contents in the seeds of three cultivars of bitter melon in the range of $383.45-440.96 \mu \mathrm{g} / \mathrm{g}$.

Iron is a key element in the metabolism of almost all living organisms. In humans, iron is an essential component of hundreds of proteins and enzymes (Rout and Sahoo, 2015). Slightly higher value was reported by Bangash et al. (2011) for iron contents $(7 \pm 0.07 \mathrm{mg} / 100 \mathrm{~g})$. However, in a recent study by Gayathri (2014) only $0.45 \pm 0.16 \mathrm{mg} / 100 \mathrm{~g}$ of iron in the fruit of bitter melon was observed. Earlier, Islam et al. (2011) also analyzed bitter melon for iron contents and found $0.9 \mathrm{mg} / 100 \mathrm{~g}$ in edible portion of bitter melon. Mathew et al. (2014) reported $22.44 \pm 0.04 \mathrm{mg} / 100 \mathrm{~g}$ of iron in the seeds of bitter melon. Ali et al. (2008) reported iron contents of $\quad 41.10 \pm 1.13 \mu \mathrm{g} / \mathrm{g}, \quad 42.57 \pm 1.47 \mu \mathrm{g} / \mathrm{g} \quad$ and $45.03 \pm 1.23 \mu \mathrm{g} / \mathrm{g}$ in their analysis on seeds of three
MAHWISH et al.

cultivars of bitter melon. Similar findings were reported by Anjum et al. (2013) on the seeds of two bitter melon cultivars and reported iron contents of $49.21 \pm 1.02 \mu \mathrm{g} / \mathrm{g}$ and $43.06 \pm 1.04 \mu \mathrm{g} / \mathrm{g}$.

The results of present study regarding zinc contents are in agreement with the findings of Bangash et al. (2011) who reported $0.85 \pm 0.08$ $\mathrm{mg} / 100 \mathrm{~g}$ of zinc in bitter melon fruit. However, Ismail et al. (2011) calculated amount of zinc in bitter melon and found lesser amount $(0.4 \mathrm{mg} / 100 \mathrm{~g})$ in fruit of this plant. Mathew et al. (2014) reported higher amount of zinc $(3.45 \pm 0.30 \mathrm{mg} / 100 \mathrm{~g})$ in the seeds of bitter melon. Earlier, Anjum et al. (2013) reported zinc contents of $12.91 \pm 0.29$ and $10.88 \pm 0.31$ in the seeds of two cultivars of bitter melon. Horax et al. (2010) showed higher amount of zinc in pericarp $(33-57 \mu \mathrm{g} / \mathrm{g})$ than the seed (12-22 $\mu \mathrm{g} / \mathrm{g})$.

\section{Phytochemical screening}

Phytochemical analysis (Table 3) clearly revealed that different bitter melon cultivars possessed almost similar kinds of phytochemicals although their abundance may vary as in case of ascorbic acid contents. The data (Table 4) also indicated that phenols, flavanoids, saponins and ascorbic acid are present in abundance in skin and flesh while seeds are rich in alkaloids and glycoalkaloid.

Table 3. Phytochemical analysis of different bitter melon cultivars.

\begin{tabular}{|c|c|c|c|c|c|c|}
\hline & Phenols & Flavanoids & Saponins & Alkaloids & $\begin{array}{c}\text { Ascorbic } \\
\text { acid }\end{array}$ & Glycoalkaloid \\
\hline Noor & + & + & + & + & $+/-$ & $+/-$ \\
\hline BG 20 & + & + & + & + & + & $+/-$ \\
\hline Black King & + & + & + & + & ++ & $+/-$ \\
\hline FSD Long & + & + & + & + & ++ & $+/-$ \\
\hline KHBG-1 & + & + & + & + & + & $+/-$ \\
\hline GHBG-1 & + & + & + & + & $+/-$ & $+/-$ \\
\hline
\end{tabular}

$+=$ indicates presence of chemical groups; $+/+=$ indicates abundance of chemical group; $+/-=$ indicates paucity of chemical group. 
Table 4. Phytochemical analysis of skin, flesh and seeds.

$\begin{array}{lll}\text { Skin } & \text { Flesh } & \text { Seeds }\end{array}$

Phenols

Flavanoids

Saponins

Alkaloids

Ascorbic acid

Glycoalkaloid
$++$

$++$

$+$

$+$

$++$

$+/-$
$++$

$++$

$++$

$+1-$

$+$

$++$

$+1-$
$++$

$+$

$+$

$++$

$+=$ indicates presence of chemical groups; $+/+=$ indicates abundance of chemical group $;+/=$ indicates paucity of chemical group.

Presence of phytochemicals in bitter melon suggests use of this plant for medicinal purposes. Previous reports also highlighted medicinal properties of these secondary metabolites (BANSO; ADEYEMI, 2007; TEMITOPE; OMOTAYO, 2012, OYEYEMI et al. 2014). The phytochemical profile in present study was similar to the earlier findings of Santhi et al. (2011) and Annapoorani and Manimegalai (2013). Presence of phenolic compounds are considered beneficial as they are helpful in boosting human health as well as decrease the risk of degenerative diseases by reduction of oxidative stress and inhibition of macromolecular oxidation (PEREIRA et al., 2007). Appreciable quantity of flavonoids has exhibited anti-oxidant, free radical scavenging activity and minimizes rapid proliferation of cells (FARQUAR, 1996). Saponins are important anti-carcinogenic agent, immune booster and helpful in lowering the cholesterol level (SODIPO et al., 2000). The presence of alkaloids suggests analgesic, anti-inflammatory and disease resistance properties of this plant (GUPTA, 1994).

Bitter melon becomes valuable because it contained ascorbic acid which is required in high amount as it is a water-soluble vitamin and lost frequently from the body. Glycoalkaloid found particularly in the seeds is one of the anti-diabetic components of bitter melon (TAN et al., 2008).

Bitter melon contained adequate amount of important minerals and phytochemicals. The variations in chemical moieties in different cultivars are due to less adaptation of exotic cultivars in changed environment.

\section{CONCLUSIONS}

The findings imply that bitter melon cultivars vary in amount of minerals and phytochemicals when planted in a changed habitat.

The indigenous cultivars (Black king and FSD Long) were assessed to be better in local climatic conditions than the exotic cultivars.

The variations in the chemical composition in fruit and components of selected cultivars suggest that selection of cultivar should not merely depend on yield.

Chemical moieties in fruit elements must be monitored in crop breeding programs so as to obtain fruits with high nutritive values to be used in diet plan strategies, feed formulations and therapeutic purposes.

RESUMO: O presente estudo foi projetado para comparar os teores de minerais e fitoquímicos em frutos de alguns cultivares indígenas e exóticos de melão amargo. Casca, polpa, sementes e frutos inteiros de cada cultivar foram secos à temperatura ambiente e moídos até obter-se um pó fino que foi embalado separadamente em frascos de plástico 
hermeticamente fechados para análise. Os dados revelaram que todos os cultivares possuíam quantidade apreciável de minerais. Cultivares indígenas possuíam maior conteúdo mineral que os cultivares exóticos. Descobriu-se que o Black King foi o cultivar desejável com alta quantidade de potássio, fósforo, magnésio, cálcio, ferro e zinco com valores de 258.83, 92.92, 46.74, 48.42, 3.90 e $1.78 \mathrm{mg} / 100 \mathrm{~g}$, respectivamente. Entre as partes das frutas, a polpa era mais rica em potássio, fósforo, magnésio, sódio e cálcio, seguida pela casca e pela semente. As sementes possuíam quantidades relativamente elevadas de ferro $(4.44 \mathrm{mg} / 100 \mathrm{~g})$ e zinco $(2.80 \mathrm{mg} / 100 \mathrm{~g})$. No geral, na polpa do Black King predomina o perfil mineral, enquanto uma menor quantidade foi observada nas sementes de Noor. Todos os cultivares possuíam os mesmos tipos de fitoquímicos, embora possam variar em sua abundância. Fenóis, flavonóides, saponinas e ácido ascórbico estavam presentes em abundância na casca e na polpa enquanto as sementes eram ricas em alcalóides e glicoalcalóides. As variações na composição química de frutos e componentes devido a mudanças nas condições agroclimáticas sugerem que há espaço para o desenvolvimento de cultivares a serem cultivadas em ampla escala de condições agronômicas, climáticas e geográficas, sem efeito no seu perfil nutricional e fitoquímico.

PALAVRAS-CHAVE: Melão Amargo. Momordica charantia. Minerais. Fitoquímicos.

\section{REFERENCES}

AHMED, D.; CHAUDHARY M. A. Medicinal and nutritional aspects of various trace metals. Journal of Advanced Scientific Research, India, v. 5, n. 7, p. 864-869, 2009.

ALI, M. A.; SAYEED, M. A.; REZA, M. S.; YEASMIN, M. S.; KHAN A. M. Characteristics of seed oils and nutritional compositions of seeds from different varieties of Momordica charantia Linn. cultivated in Bangladesh. Czech Journal of Food Sciences, Czech Republic, v. 26, p. 275-283, 2008. https://doi.org/10.17221/1123-CJFS

ANJUM, F.; SHAHID, M.; BUKHARI, S. A.; ANWAR, S.; LATIF, S. Study of quality characteristics and efficacy of extraction solvent/ technique on the antioxidant activity of bitter gourd Seed. Journal of Food Processing \& Technology, China, v. 4, n. 2, p. 1-8, 2013.

ANNAPOORANI, C. A.; MANIMEGALAI, K. Screening of medicinal plant Mormordica charantia leaf for secondary metabolites. International Journal of Research and Development in Pharmacy \& Life Sciences, India, v. 5, n. 3, p. 001-006, 2013.

ASLAM, M. W.; ASIMULLAH, F. K.; KHAN, I.; JAN, S.; MUHAMMAD, N.; KHAN, R. I.; SAEED, A.; BOKHARI, T. H. Dietary and trace elements evaluation of elected vegetables from North Waziristan Agency, KPK Pakistan. Journal of Medicinal Plants Research, Nigeria, v. 7, n. 44, p. 3232-3236, 2013.

ASSUBAIE, N. F.; EL-GARAWANY, M. M. Evaluation of some important chemical constituents of Momordica charantia cultivated in Hofuf, Saudi Arabia. The Journal of Biological Sciences, India, v. 4, p. 628-630, 2004. https://doi.org/10.3923/jbs.2004.628.630

BAKARE, R. I.; MAGBAGBEOLA, O. A.; AKINWANDE, A. I.; OKUNOWO, O. W. Nutritional and chemical evaluation of Momordica charantia. Journal of Medicinal Plants Research, Nigeria, v. 4, n. 21, p. 2189-2193, 2010.

BANGASH, J. A.; ARIF, M.; KHAN, F.; KHAN, F.; RAHMAN, A.; HUSSAIN, I. Proximate composition, minerals and vitamins content of selected vegetables grown in Peshawar. Journal of Chemical Society of Pakistan, Pakistan, v. 33, p. 118-122, 2011.

BANSO, A.; ADEYEMO, S. O. Evaluation of antibacterial properties of tannins isolated from Dichrostachys anera. African. Journal of Biotechnology, Austria, v. 6, n. 15, p. 785-1787, 2007.

DREWNOWSKI, A.; GOMEZ-CARNEROS, C. Bitter taste, phytonutrients, and the consumer: a review. The American Journal of Clinical Nutrition, USA, v. 72, n. 6, p. 1424-35, 2000.

https://doi.org/10.1093/ajen/72.6.1424 
FARQUAR, J. N. Plant Sterols, their biological effects in human. Handbook of Lipids in Nutrition BOCA: Rotan HL CRC Press, 1996.

GUPTA, S. S. Prospects and perspective of natural plant products. Indian Journal of Pharmacology, India, v. 26, n. 1, p. 1-12, 1994.

HARBORNE, J. B. Phytochemical methods. A guide to modern techniques of plant analysis. 3. ed. New Delhi: Springer Pvt. Ltd., 2005.

HORAX, R.; HETTIARACHCHY, N.; KANNAN, A.; CHEN, P. Y. Proximate composition and amino acid and mineral contents of Mormordica charantia L. pericarp and seeds at different maturity stages. Food Chemistry, UK, v. 122, n. 4, p. 1111-1115, 2010. https://doi.org/10.1016/j.foodchem.2010.03.093

ISLAM, S.; JALALUDDIN, M.; HEITTIARACHCHY, N. S. Bio-active compounds of bitter melon genotypes (Momordica charantia L.) in relation to their physiological functions. The Journal of Functional Foods in Health and Disease, USA, v. 2, p. 61-74, 2011.

ISMAIL, F.; ANJUM, M. R.; MAMON, A. N.; QAZI, T. G. Trace metal content of vegetables and fruits of Hyderabad retail market. Pakistan Journal of Nutrition, Pakistan, v.10, n. 4, p. 365-372, 2011. https://doi.org/10.3923/pjn.2011.365.372

JAYASINHA, P.; WARNASURIYA, D.; DISSANAYAKE, H. Momordica charantia-a literature survey. Medicinal and aromatic plant series. Colombo information services centre: Industrial Technology Institue, Sri Lanka. v. 3, p. 36, 1999.

KAR, A.; CHOUDHARY, B. K.; BANDYOPADHYAY, N. G. Preliminary studies on the inorganic constituents of some indigenous hypoglycaemic herbs on oral glucose tolerance test. Journal of Ethnopharmacology, Netherlands, v. 64, n. 2, p. 179-84, 1999. https://doi.org/10.1016/S0378-8741(98)001184

KRAWINKEL, M. B.; KEDING, G. B. Bitter gourd (Momordica charantia L.): a dietary approach to hyperglycemia. Nutrition Reviews, USA, v. 7, p. 331-337, 2006. https://doi.org/10.1301/nr.2006.jul.331-337 https://doi.org/10.1111/j.1753-4887.2006.tb00217.x

MATHEW, T. J.; NDAMITSO, M. M.; OTORI, A. A.; SHABA, E. Y.; INOBEME, A.; ADAMU, A. Proximate and mineral compositions of seeds of some conventional and non-conventional fruits in Niger State, Nigeria. Academic Research International, Nigeria, v. 5, n. 2, p. 113-118, 2014.

NAIK, P. Biochemistry. Jaypee Brothers Medical Publishers. 4. ed. New Delhi: India, 2016.

OBADONI, B. O.; OCHUKO, P. O. Phytochemical studies and comparative efficacy of the crude extract of some homeostatic plants in Edo and Delta states of Nigeria. Global Journal of Pure and Applied Sciences, Nigeria, v. 8, p. 203-208, 2001.

OYEYEMI, S. D.; AROWOSEGBE, S.; ADEBIYI, A. O. Phytochemical and proximate evaluation of Myrianthus arboreus (P. Beau.) and Spargonophorus sporgonophora (Linn.) leaves. IOSR Journal of Agriculture and Veterinary Science. Nigeria, v. 7, n. 9, p. 01- 05, 2014.

PAPUC, C.; POP, A.; SERBAN, M. Metode Analitice in Biochimia Veterinara; Editura Printech, Bucharest: Romania, 2001.

PAUL, A.; RAYCHAUDHURI, S. S. Medicinal uses and molecular identification of two Momordica charantia varieties - a review. Electronic Journal of Biology, USA, v. 6, n. 2, p. 43-51, 2010. 
PEREIRA, A. P.; FERREIRA, I. C. F. R.; MARCELINO, F.; VALENTÃO, P.; ANDRADE, P. B.; SEABRA, R.; ESTEVINHO, L.; BENTO, A.; PEREIRA, J. A. Phenolic compounds and antimicrobial activity of olive (Olea europaea L. Cv. Cobrançosa) Leaves. Molecules, Switzerland, v. 12, n. 5, p. 1153-1162, 2007. https://doi.org/10.3390/12051153

PETERS, B. S.; MARTINI, L. A. Nutritional aspects of the prevention and treatment of osteoporosis. Arquivos Brasileiros de Endocrinologia \& Metabologia, Brazil, v. 54, n. 2, p. 179-185, 2010. https://doi.org/10.1590/S0004-27302010000200014

ROUT, G. R.; SAHOO, S. Role of iron in plant growth and metabolism. Reviews in Agricultural Science, Japan, v. 3, p. 1-24, 2015. https://doi.org/10.7831/ras.3.1

SANTHI, R.; LAKSHMI, G.; PRIYADHARSHINI, A. M.; ANANDARAJ, L. Phytochemical screening of Nerium oleander leaves and Momordica charantia leaves. International Research Journal of Pharmacy, India, v. 2, n. 1, p. $131-135,2011$.

SINGLETON, V. L.; ORTHOFER, R.; LAMUELA-RAVENTOS, R. M. Analysis of total phenols and other oxidation substrates and antioxidants by means of Folin- Ciocalteu reagent. Methods in Enzymology, Netherlands, v. 299, p. 152-178, 1999. https://doi.org/10.1016/S0076-6879(99)99017-1

SODIPO, A. O.; AKINIYI, J. A.; OGUNBAMOSU, J. A. Studies on certain characteristics of extracts of bark of Pansinystalia macruceras (K schemp) Pierre Exbeille. Global Journal of Pure and Applied Sciences, Nigeria, v. 6, p. 83-87, 2000.

SOOMRO, A. K.; ANSARI, K. A. Medicinal uses of Bitter gourd (Momrdica charantia). Hamdard Medicine, Pakistan, v. 48, p. 9-14, 2005.

TAN, M.; JI-MING, Y.; NIGEL, T.; CORDULA, H.; CHANG-QIANG, K. Antidiabetic activities of Triterpenoids isolated from bitter melon associated with activation of the AMPK pathway. Chemistry \& Biology, Netherlands, v. 15, n. 3, p. 263-73, 2008. https://doi.org/10.1016/j.chembiol.2008.01.013

TAYLOR, L. Herbal secrets of the rainforest. In: Texas A, editor. Bitter melon (Momordica charantia). 2. ed. Sage Press: USA, p. 1-100, 2002.

TEMITOPE, I. B.; OMOTAYO, F. O. Comparative Phytochemical analysis of selected medicinal plants in Nigeria. The International Journal of Advanced Chemical Research, India, v. 1, n. 1, p. 011-018, 2012.

ULLAH, A.; KARIM, F.; SARKAR, S. K.; ISLAM, M. K.; ABSAR, N. Nutrient and phytochemical analysis of four varieties of bitter melon (Momordica charantia) grown in Chittagong Hill Tracts, Bangladesh. Asian Journal of Agricultural Research, UAE, v. 5, n. 3, p. 186-193, 2011. https://doi.org/10.3923/ajar.2011.186.193

UMESAWA, M.; ISO, H.; DATE, C.; YAMAMOTO, A.; TOYOSHIMA, H.; WATANABE, Y.; KIKUCHI, S.; KOIZUMI, A.; KONDO, T.; INABA, Y.; TANABE, N.; TAMAKOSHI, A. Relations between dietary sodium and potassium intakes and mortality from cardiovascular disease: the Japan Collaborative Cohort Study for Evaluation of Cancer Risks. The American Journal of Clinical Nutrition, USA, v. 88, n. 1, p. 195-202, 2008. https://doi.org/10.1093/ajcn/88.1.195

WHITE, J. Testing for glycoalkaloids. National Institute of Agricultural Botany. Cambridge University Press: UK, 1987.

ZOU, Y.; LU, Y.; WEI, D. Antioxidant activity of flavonoid-rich extract of Hypericum perforatum L in vitro. Journal of Agricultural and Food Chemistry, USA, v. 52, p. 5032-5039, 2004. https://doi.org/10.1021/jf049571r 